\title{
Editorial
}

\section{The new globalisation, food and health: is public health receiving its due emphasis?}

Increasingly over the past two decades, governments around the world have been telling their citizens that the old era of looking to the state to resolve public policy problems is over. This experiment in reducing social aspirations has been closely associated with the globalisation process. At its crudest, the argument is that unless citizens work harder and longer, other workforces in unspecified but distant lands will be more competitive than they. Pressure to hold or reduce public spending such as on health and welfare and to increase efficiency quickly follows. ${ }^{1}$ World competitiveness league tables are routinely published judging national economies against each other. ${ }^{2}$ A certain public policy neurosis has been observable even within developed economic blocs such as the European Union ${ }^{3}$ and certainly in Britain. ${ }^{4}$

More sophisticated analyses, associated with, but not the prerogative of, the cultural theorists of post-modernity, argue that because barriers between nations are changing, a fundamental restructuring of the state is underway. Far from the state being reduced, as the ideologues of the New Right sought from the $1970 \mathrm{~s},{ }^{5}$ it is in fact being re-oriented-"reengineered" to use the vernacular - from being a provider of welfare and health services to become a facilitator and safety net of last resort. ${ }^{67}$ The British prime minister, for instance, having borrowed the "new" in New Labour from the "New" Democrats in the USA, is borrowing again when attempting to articulate a Third Way in politics, an alternative to the statism of socialism/social democracy and the injustices associated with unfettered New Right belief in markets. ${ }^{8}$ The dream is for welfare to work programmes to replace welfare.

Public health specialists should keep close attention on these issues. There are good grounds for concern, and not just about budgets. A restructuring is underway. Food and health policy is a particularly pertinent area to watch. Dietary patterns are already experiencing rapid change. Its most obvious expression is the "burgerisation" of food culture, ${ }^{9}{ }^{10}$ but behind that is a comprehensive restructuring of world agricultural markets introduced by the 1994 General Agreement on Tariffs and Trade (GATT). In the process, food security, a health goal beloved since the 1974 World Food Summit, is redefined as reliance on farm and world commodity markets rather than maximising local supplies. ${ }^{11}$ Another feature is the readiness for public health bodies to be encouraged to work with corporate interests rather than tame them, which was the hallmark of "old" public health initiatives from John Snow and the Southwark water pump onwards. In the new public health order, health is a market commodity like any other, so health planners are actively encouraged to work with those who dominate the market. Thus, health educators now liaise with supermarkets and food companies.

It is true that marketing and branding, associated with media consciousness, now have a remarkable place in people's consciousness and in reinforcing their taste for value added foods, particularly with young people and populations thirsting after a western lifestyle. They have the capacity to change food culture in remarkably short periods. ${ }^{12}$ But who is in control of this relationship? Ironically, it is being encouraged just when epidemiological and public health awareness about the growth of degenerative diseases in developing worlds, and their partial dietary aetiology, is consolidating. ${ }^{13}$ Major causes of premature death-coronary heart disease and some cancers-are spreading in the developing world as the western diet takes hold, along with other lifestyle changes. ${ }^{14}{ }^{15}$ This has immense implications both for state budgets and for inequalities in health. ${ }^{16}$

Food policy is a salutary reminder of the complexity that can be lost in an over-glib use of the term globalisation. Food has been traded for millennia. Think only of spices, fruits, wheat, rice, potatoes. ${ }^{17}$ These are all grown and consumed thousands of miles from the so called Vavilov centres whence they originated. Globalisation is nothing new in food. What is new about the modern period, however, is the pace and scale of change. ${ }^{18}$

The new era of globalisation has been characterised by an astonishingly rapid shift in national boundaries and the meaning of the nation state. The European Union, for instance, introduced the world's largest non-tariff trade area in just five years after the passing of the Single European Act in 1987. Food compositional standards were swept away and in return weak labelling information was supposed to give the consumer power to decide which product to buy: the sausage with $40 \%$ meat or one with less. Consumers have some difficulty with labels as a means for translating health desires to dietary reality, ${ }^{19}$ and the general model of consumer sovereignty and awareness has many critics, particularly from the consumer movement. ${ }^{20}{ }^{21}$

In the name of removing barriers to trade and ensuing efficiency, national food inspection systems were harmonised and border inspections reduced. Goods were to be judged safe at point of production and sale. A concept of "due diligence" was introduced under which companies are obliged to be able to show that they have done their best to achieve the highest practicable standards. While these improvements undoubtedly benefit international food traders and companies' expansion, since the BSE debacle of 1996, a sneaking feeling has emerged that public health protection has perhaps been treated too lightly. ${ }^{22}$ How can a government really instil a health education message when its budgets are tight (to keep a rein on welfare and to enhance international competitiveness) and when a multinational corporation can spend vast sums on TV advertising to encourage brand recognition ${ }^{23}$ This is already seen to be very effective. ${ }^{24}$

The question public health proponents need to ask now is: if they were ministers in a cabinet, which brief would take primacy: health or international trade? Until a crisis-as happened with BSE and its apparent transfer to humansthe answer is obvious. Trade and finance carry more clout. But can we afford for public health to be a bolt-on extra? Surely, not. It is time to argue for a better way.

A first task is to accumulate the evidence and to enter the arguments about globalisation with policy makers and, above all, the public. They, after all, are the citizens who vote. In the case of infectious diseases, the case for tough protection is strong. The World Health Organisation (WHO) has long argued the case for concern about diphtheria, cholera and diarrhoeal diseases, tuberculosis, viral 
hepatitis, AIDS, and more. ${ }^{25}$ The baseline is cause for concern enough. Ten per cent of the population of industrialised countries suffer foodborne diseases annually. With tourism on the increase, the 600 million people who travel abroad each year run an estimated $20-50 \%$ risk of contracting a foodborne illness. ${ }^{26}$ While concern about the health impact of this flow of people is growing, less attention has been accorded to the rapid rise in the distance food travels because of mass food systems. ${ }^{27}$ In the UK, for instance, the distance food travels between producer and consumer has risen by $30 \%$ in 15 years. ${ }^{28} \mathrm{~A}$ mass food system increases the chance of problems when there is a breakdown in health controls.

A second challenge is public health governance. The debate about the WHO is welcome. ${ }^{29}{ }^{30}$ Some humility is in order. In most countries, the medical professions have some kudos but even their capacity to influence governments is severely weakened if national governments' role is partly to facilitate removal of public protection powers. One public health person's good regulation is a food magnate's unnecessary burden on business. ${ }^{31}$ The 1994 GATT set up the World Trade Organisation (WTO), which has considerable force in relation to national state affairs. The WTO, already distant from world citizenry, now celebrates its proximity to major companies. ${ }^{32}$ The processes unleashed by globalisation have increased inequalities. A new world class structure is emerging, where rich and poor within a country may have a lifestyle more in common with that of their equivalents in other countries than with their compatriots. Thirty years ago, the combined incomes of the richest fifth of the world's people were 30 times greater than the poorest fifth. Today their incomes are over 60 times greater. The rise in numbers of billionaires that have benefited from free market deregulation of the global markets is now put at 358. They are collectively worth some $\$ 762$ billion, which is approximately equivalent to the combined income of the world's poorest two billion - that is, well over a third of world population. ${ }^{33}$

Despite such power, it is possible to achieve modern, tough but fair public health legislation and monitoring. The UK food and health movement has been successful in building pressure to change legislation on food safety, for example. It is possible to win public support for regulation and intervention despite political and commercial opposition. ${ }^{34}$ In the USA, after scandals about food import safety standards, the government is now seeking extra funds from Congress to toughen border food inspections. The case can be won, even within commerce, that tougher standards cost in the short-term, but pay in the long term.

Globally this task is awesome. The GATT, like many international agreements, was at pains to create a new global system to harmonise food standards. Food standards are now "influenced" by the Codex Alimentarius Commission, the joint WHO/Food and Agricultural Organisation body. Yet the corporate food giants who already dominate food trade are excessively represented at the decision making table. ${ }^{35}$ Who sets standards is now a priority issue for public health. The WTO's disputes procedure, for example, now draws upon Codex when it adjudicates on issues such as whether hormones can be used in beef rearing and, most explosively of all, whether controls over use of genetically modified organisms in foodstuffs are adequate.

The third challenge is to the narrow consumerist notion of choice. Choice is the ideological yardstick by which much modern food policy is judged, yet there is a strong case that choice is over-vaunted. ${ }^{36}$ Do people really choose their diets? The hypermarket contains 20000 or more items, but we use only a few. The veneer of choice is well understood in environmental health-climate change for instance. ${ }^{37}$ Few people believe they can control their air or on their own repair the ozone layer, yet the modern era has implied that diet is an individual responsibility. The new public health analysis suggests that the factors that determine what we eat, let alone its health impact, are more given and moulded than chosen. We might believe we all choose our diet, but it is remarkable how birth, genes, culture, and class differentiate between us. ${ }^{38}$ Did John Snow give the citizens of Southwark a choice to draw polluted water from the pump? Seemingly no politician today will give public health agencies the power to introduce tough pro-active food and health policies unless there is a crisis - as there loomed with AIDS in the 1980s or happened with BSE-CJD in 1996. Has the pendulum been swung too far away from control in favour of choice? Consumerism is not the same thing as citizenship.

TIM LANG

Centre for Food Policy, Wolfson Institute of Health Sciences, Thames

Valley University, 32-38 Uxbridge Road, Ealing, London W5 2BS

1 Lang, T, Hines, C. The new protectionism. London: Earthscan, 1993.

2 OECD. The OECD jobs study: evidence and explanations. Paris: Organisation

3 Cor Economic Co-operation and Development, 1994. employment: the challenges and ways forward into the $21^{\text {st }}$ century: White Paper. employment: the challenges and ways forward into the $21^{t 1}$ century: White Paper.
Bulletin of the European Communities, Supplement 6/93, Brussels: CEC, Bullet. 1993.

4 Chote R. Poor management blamed for low output. Financial Times May 15, 1997.

5 Cockett R. Thinking the unthinkable: think-tanks and the economic counterrevolution 1931-1983. London: HarperCollins, 1994

6 Hirst P, Thompson G. Globalisation in question. Cambridge: Polity Press, 1996.

7 Mulgan G. Connexity. London: Chatto and Windus, 1997.

8 Kettle M. Why we can make a difference: interview with Tony Blair MP. The Guardian May 15, 1998.

9 Ritzer G. The McDonaldization of society. Thousand Oaks, CA: Pine Forge Press, 1993.

10 Vidal J. McLibel: burger culture on trial. London: Pan, 1997.

11 Lang T. Food security: does it conflict with globalization? Development $1996 ; 4: 45-50$

12 Barnet R, Cavanagh J. Global dreams. New York: Simon and Schuster, 1995.

13 Cannon G. Food and health: the experts agree. London: Consumers' Assocation, 1992 .

14 Drewnoski A, Poplin K. The nutrition transition: new trends in the global diet. Nutr Rev 1997;55:31-43.

15 WCRF. Food, nutrition and the prevention of cancer. Washington DC: World Cancer Research Fund /American Institute for Cancer Research, 1997: chapter 9 .

16 Popkin B M. The nutrition transition in low-income countries: An emerging crisis. Nutr Rev 1994;52:285-98

17 Hobhouse H. Seeds of change: five plants that transformed mankind. London: Macmillan, 1992.

18 Lang T. The public health impact of globalisation of food trade. In: Shetty $\mathrm{P}, \mathrm{McPherson} \mathrm{K}$, eds. Diet, nutrition and chronic disease: lessons from contrasting worlds. London: J Wiley, 1997: 173-87.

19 Black A, Rayner M. Fust read the label. London: HMSO, 1992.

20 Gabriel Y, Lang T. The unmanageable consumer. London: Sage, 1995.

21 Lansley S. After the gold rush: the trouble with affluence. London: Century, 1995.

22 Rayner M. Health promotion and the world trade in food: any connection? European Heart Network General Assembly and Workshop. Dublin: 8-10 May 1996. Oxford: British Heart Foundation.

23 Longfield J. Advertising and labelling - how much influence? In: National Consumer Council, ed. Your food: whose choice? London: HMSO, 1992.

24 Dibb S. Children: advertisers' dream, nutrition nightmare? London: National Food Alliance, 1993.

25 World Health Organisation. Communicable diseases won't stop at a border crossing. Copenhagen: World Health Organisation Regional Office for Europe, 1996.

26 Kaeferstein FK, Motarjemi Y, Bettcher DW. Foodborne disease control: a transnational challenge. Emerging Infectious Diseases 1997;3:503-10.

27 Raven H, Lang T. Off our trolleys?: food retailing and the hypermarket economy. London: Institute for Public Policy Research, 1995.

28 Paxton A. The food miles report. London: Sustainable Agriculture, Food and Environment Alliance, 1994 .

29 Lee K, Collinson S, Walt G, Gilson L. Who should be doing what in international health: a confusion of mandates in the United Nations? BMf 1996;312:302-27.

30 Walt G. Globalisation of international health. Lancet 1998;351:434-7.

31 Haskins C. Rules and more rules. Financial Times May 13,1995.

32 World Trade Organisation. Major companies to participate in WTO trade facilitation symposium. Press Release 3 March 1998, 98-0847.

33 Cavanagh J, Broad R. Understanding north-south political economy in the 1990s. Washington DC: Institute for Policy Studies, November, 1994

34 Lang T. Going public: food campaigns during the 1980s and 1990s. In: Smith D, ed. Nutrition scientists and nutrition policy in the 20th century. London: Routledge, 238-60.

35 Avery N, Drake M, Lang T. Cracking the Codex, report for 50 consumer NGOs. London: National Food Alliance, 1993

36 Gabriel Y, Lang T, The unmanageable consumer. London: Sage, 1995: chapter 2 .

37 McMichael AJ, Haines A, Slooff R, et al, eds. Climate change and human health. Geneva: World Health Organisation, UN Environment Programme, health. Geneva: World Health Organisation,

38 Fieldhouse P. Food and nutrition: customs and culture. London: Chapman and Hall, 1995. 